\title{
Konflik Kepentingan Dalam Pengelolaan Masjid Besar Kauman Yogyakarta
}

\section{Muhammad Chawari}

Keywords: cultural resource management, conservation, protection, utilization, islam, kraton

\section{How to Cite:}

Chawari, M. (2005). Konflik Kepentingan Dalam Pengelolaan Masjid Besar Kauman Yogyakarta. Berkala Arkeologi, 25(1), 97-109. https://doi.org/10.30883/jba.v25i1.914

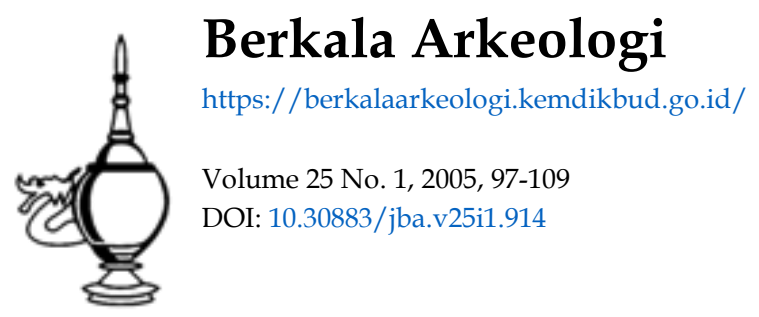

\section{(c) (1) (2) (2)}

This work is licensed under a Creative Commons Attribution-NonCommercial-ShareAlike 4.0 International License. 


\section{KONFLIK KEPENTINGAN DALAM \\ PENGELOLAAN MASJID BESAR KAUMAN YOGYAKARTA}

Oleh : Muhammad Chawari

\section{A. Latar Belakang Permasalahan}

Secara administratif Masjid Besar Kauman (selanjutnya cukup dengan istilah MBK) Yogyakarta terletak di Kampung Kauman, Kecamatan Gondomanan, Kotamadia Yogyakarta. Masjid ini merupakan masjid kerajaan Kasultanan Yogyakarta yang didirikan 18 tahun setelah sultan mendirikan keraton, yaitu pada tahun 1773 M dan ruangan serambi pada tahun 1775 M (Chawari, 1989).

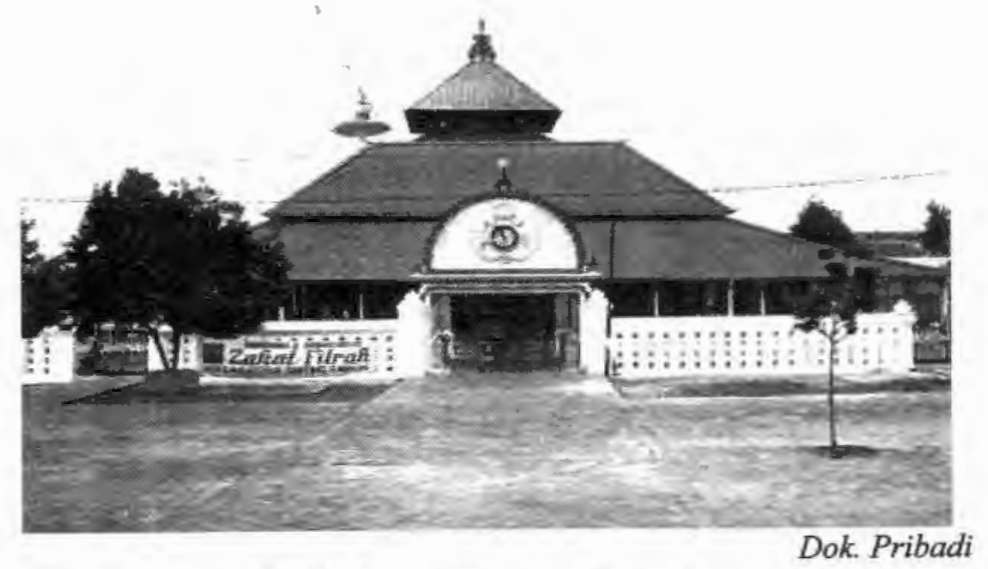

Masjid Besar Kauman Yogyakarta dilihat dari arah timur

MBK termasuk salah satu tinggalan budaya yang ada di Yogyakarta dan tergolong dalam Benda Cagar Budaya yang dilindungi keberadaannya sesuai dengan UU No. 5 Tahun 1992. Meskipun demikian secara yuridis formal MBK ini belum ada Surat Keputusan tentang penetapan $\mathrm{BCB}$, tetapi berdasarkan nilai penting kesejarahan, ilmu pengetahuan, dan kebudayaan, serta kepariwisataan mestinya telah ada dan ditetapkan sesuai dengan peraturan UU seperti tersebut di atas. MBK ini telah beberapa kali mendapatkan perhatian khusus dari instansi pemerintah yang berkompeten terhadap BCB ini. Hal ini terbukti dengan telah dilakukannya konservasi dan restorasi beberapa kali, antara lain oleh Kantor Suaka Peninggalan Sejarah dan Purbakala Prop. D.I. Yogyakarta (sekarang BP3) pada tahun 1988, 2002, dan 2004, sedangkan Kantor Dinas Kebudayaan dan Pariwisata Prop. D.I. Yogyakarta pada tahun 2002, 2003, dan 2004.

Sebagaimana masjid-masjid lain yang mempunyai makna kesejarahan yang cukup tinggi, misal: Masjid Agung Demak, Masjid Agung Surakarta, Masjid Kanoman dan Kasepuhan di Cirebon dll, hal ini merupakan daya tarik tersendiri sehingga MBK sering mendapat perhatian dari wisatawan, baik wisatawan nusantara maupun wisatawan mancanegara. Meskipun demikian pada waktu-waktu tertentu jumlah wisatawan meningkat secara menyolok, terutama pada waktu liburan 
sekolah. Sementara di luar waktu liburan sekolah, kebanyakan yang datang adalah wisatawan "wali songo". Wisatawan jenis ini adalah wisatawan yang berasal tidak hanya dari Jawa, tetapi juga dari Sumatera, Kalimantan, Sulawesi, dan daerah Nusatenggara. Menurut informasi salah seorang wisatawan, mereka dalam kunjungannya mempunyai maksud-maksud tertentu yang berkaitan dengan ziarah. Biasanya wisatawan "wali songo" dalam ziarah sudah mempunyai jalur tertentu, dimulai dari tempat-tempat "keramat" yang ada di Pantai Utara Jawa dan berakhir di daerah pedalaman Jawa (antara lain Masjid Besar Kauman).

Dengan banyaknya jumlah pengunjung yang hampir merata setiap bulan dalam satu tahun tentunya akan mengundang masyarakat yang ada di sekitar MBK untuk dapat memanfaatkan kesempatan tersebut, yaitu dalam bentuk jasa. Kegiatan dalam bentuk jasa yang dilakukan oleh warga masyarakat di sekitar MBK sedikit banyak tentunya akan "mengganggu" kelestarian BCB tersebut. Bentuk jasa yang dilakukan warga sekitar MBK meliputi: penginapan, pelayanan jasa kamar mandi, pedagang kaki lima, pelayanan jasa parkir kendaraan bermotor, pengemis, dan tukang becak. Seiring dengan perkembangan waktu keberadaan mereka dikhawatirkan mengundang adanya konflik berkepanjangan dan akibatnya akan mengganggu pengelolaan (pelestarian dan pemanfaatan) MBK di masa yang akan datang.

\section{B. Sumber dan Bentuk Konflik Yang Ada}

\section{Penginapan}

Sumber konflik yang berkaitan dengan penginapan timbul karena adanya oknum-oknum yang mengatasnamakan pengurus takmir MBK menggunakan serambi masjid sebagai tempat menginap bagi para wisatawan. Sementara itu, pengurus takmir MBK, sebagai pengelola resmi yang diberi mandat oleh kraton Yogyakarta selaku pemilik resmi BCB melalui Kawedanan Pengulon tidak menghendaki adanya penginapan dengan menggunakan bagian-bagian masjid, apalagi serambi yang berbatasan langsung dengan ruang inti masjid. Kebijakan ini diterapkan mengingat keberadaan para wisatawan yang menginap sangat mengganggu kegiatan sholat jama'ah yang ada di dalamnya, khususnya pada saat jama'ah sholat subuh yang berlangsung antara jam 04.00 s.d. 05.00. Gangguan yang ditimbulkan para penginap yaitu:

a. Di satu pihak di dalam masjid sedang dilaksanakan jama'ah sholat subuh, sementara di pihak lain para wisatawan masih tidur, bahkan ada yang mendengkur.

b. Keadaan seperti tersebut di atas sangat mengganggu pemandangan jama'ah yang melewati serambi, sebab serambi merupakan salah satu akses untuk menuju ruang utama masjid.

c. Adanya suara gaduh yang ditimbulkan oleh para wisatawan menjelang dan pada saat mereka bangun. 
d. Para jama'ah yang akan menggunakan kamar mandi harus menunggu para wisatawan yang telah lebih dulu memakainya, sedangkan kegiatan sholat jama'ah subuh sudah dimulai.

Para wisatawan yang menginap ditarik biaya oleh oknum-oknum yang mengatasnamakan pengurus masjid, sedangkan biaya yang mereka tarik tidak masuk ke kas takmir MBK.

\section{Kamar Mandi}

Di kompleks MBK terdapat dua jenis kamar mandi yang dibedakan atas dasar keletakannya, yaitu kamar mandi dalam dan kamar mandi luar. Kamar mandi dalam terletak di dalam tembok keliling masjid dan tidak dipungut bayaran, sedangkan kamar mandi luar terletak di luar tembok keliling masjid, yaitu di bagian halaman masjid dan dipungut biaya. Pengurus takmir MBK telah menetapkan bahwa kamar mandi dalam dikhususkan bagi para jama'ah yang akan melaksanakan ibadah di masjid, baik jama'ah yang berasal dari lingkungan sekitar objek maupun jama'ah yang berasal dari wisatawan. Sementara kamar mandi luar yang diperuntukkan bagi wisatawan yang berkunjung ke masjid tetapi tidak untuk beribadah, hanya sekedar "transit" untuk melepaskan lelah setelah mengunjungi objek-objek wisata yang ada di Yogyakarta dan sekitarnya. Ketentuan tersebut diberlakukan mengingat bahwa kamar mandi dalam jumlahnya tidak sebanyak kamar mandi luar.

Sebagai bahan perbandingan jumlah kamar mandi pada masing-masing tempat, yaitu:

a. Kamar mandi luar berjumlah 14 buah.

b. Kamar mandi dalam berjumlah 12 buah. Dari jumlah tersebut terbagi menjadi 4 buah digunakan oleh orangorang (oknum) tertentu untuk kepentingannya sendiri yaitu dengan menarik uang, dan 8 buah yang secara langsung dapat dipakai oleh para jama'ah.

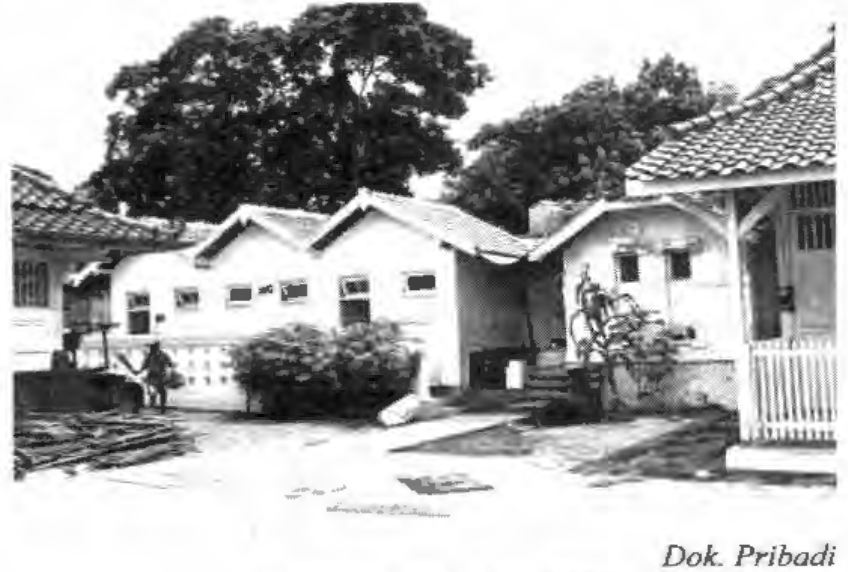

Kamar mandi dan WC khusus untuk wisatawan

Dengan melihat hal tersebut dapat diketahui bahwa sumber konflik berasal dari dalam dan dari luar objek, yaitu: 
a. Konflik dari luar $\rightarrow$ para pengunjung yang datang bertujuan tidak untuk berjama'ah, tetapi sekedar lewat untuk istirahat sebentar sebelum melanjutkan perjalanan pulang.

b. Konflik dari dalam $\rightarrow$ disebabkan oleh beberapa oknum yang memanfaatkan empat buah kamar mandi untuk kepentingannya, yaitu dengan jalan menempatkan kotak di depan kamar mandi. Orangorang yang telah memanfaatkan jasa kamar mandi agar mengisi kotak tersebut, hasilnya tidak masuk ke kas Takmir Masjid, tetapi untuk kepentingan pribadi oknum-oknum tersebut. Anehnya mereka merupakan petugas kebersihan yang telah diangkat dan

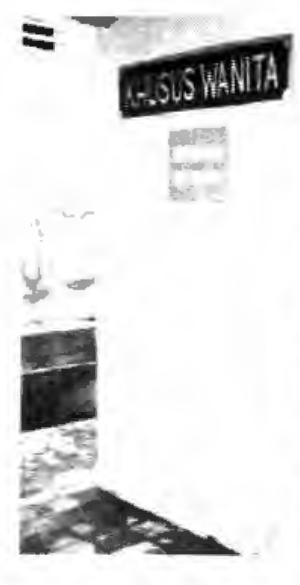

Kamar mandi dan WC yang telah Dok. Pribadi dimanfaatkan oknum tertentu ditetapkan oleh pengurus takmir MBK.

\section{Pengemis}

Konflik yang diakibatkan oleh pengemis di MBK dan sekitarnya sebetulnya belum seperti yang terjadi di tempat-tempat lain, karena jumlahnya belum banyak. Pada umumnya mereka memilih lokasi di depan pintu masuk dan di sekitar regol masjid. Keberadaan pengemis tersebut terjadi hanya pada waktuwaktu tertentu saja, yaitu setiap hari Jum'at (khususnya) dan pada waktu adanya upacara-upacara keagamaan yang dilakukan oleh pihak kraton Yogyakarta. Upacara-upacara tersebut antara lain Sekaten, Grebeg Maulud, Grebeg Besar (sesudah sholat 'Idul Adha), dan Grebeg Syawal (sesudah sholat 'Idul Fitri). Mengapa keberadaan mereka terutama pada hari Jum'at? Tentunya hal ini penuh dengan perhitungan, yaitu agar para jama'ah sesudah melaksanakan sholat Jum'at memberikan sekedar uangnya kepada fakir miskin sebagai bagian dari sedekah mereka, seperti yang dianjurkan dalam agama Islam agar memperbanyak amalan terutama kepada kaum yang tergolong tidak mampu yang nantinya akan memperoleh imbalan berlipat ganda pada hari akhir. Melihat keadaan para pengemis tersebut kelihatan bahwa kegiatan tersebut sudah merupakan "mata pencaharian" mereka. Jika dilihat secara seksama uang yang mereka terima dari masing-masing jama'ah sebetulnya tidak banyak, rata-rata Rp. 100,-, tetapi jika dikaitkan dengan jumlah jama'ah tentunya hasil yang mereka peroleh lumayan banyak juga.

"Gangguan" yang mereka timbulkan adalah keberadaan mereka selalu di depan pintu rnasjid dan regol dengan menyodorkan "wadah" agar para jama"ah 
memberi sekedar uang. Keadaan ini sangat mengganggu lalu lintas masuk dan keluar jama'ah dari dan ke MBK. Selain itu, kadang-kadang mereka disertai anak-anaknya yang akan selalu mengikuti para jama'ah yang keluar dari masjid sebelum memberikan uang sekedarnya kepada mereka.

\section{Pedagang Kaki Lima}

Pada dasarnya kelompok Pedagang Kaki Lima (PKL) yang ada di sekitar MBK sudah dikoordinir dalam sebuah wadah yang dinamakan Paguyuban Pedagang Kaki Lima Sekitar Kraton (PPKLSK) dengan jumlah anggota sekitar 50 orang. Kelompok ini dapat digolongkan menjadi 3 jenis, yaitu:

a. Kelompok menetap. Para Pedagang Kaki Lima ini pada dasarnya sudah ditempatkan di tempat yang sudah disediakan, yaitu di pinggir jalan sebelah barat Jalan Pekapalan Alun-alun Utara Yogyakarta. Walaupun tempat ini sebenarnya merupakan fasilitas umum untuk pejalan kaki, berupa trotoar. Pada saat-saat tertentu, misalnya musim liburan, kelompok ini dalam menjajakan dagangannya ditempatkan di pinggir jalan hingga sepertiga lebar jalan. Hal ini yang tidak mereka sadari bahwa keberadaan mereka dengan menggelar dagangan di pinggir jalan dapat membuat kesan tidak teratur dalam penataannya. Selain itu, mengurangi hak pemakai jalan yang lewat di sekitar jalan tersebut, termasuk akses wisatawan yang akan mengunjungi MBK.

b. Kelompok semi menetap. Kelompok ini merupakan pedagang souvenir, pakaian, dan makanan yang membuat kios baru tidak permanen di pinggir alun-alun sebelah dalam dengan memakai tenda. Hal ini disebabkan makin banyak pedagang-pedagang baru yang ingin berjualan. Lokasi ini sebenarnya merupakan tempat yang bebas dari bangunan apapun, kecuali pada saat adanya perayaan Sekaten. Selain itu, alun-alun merupakan

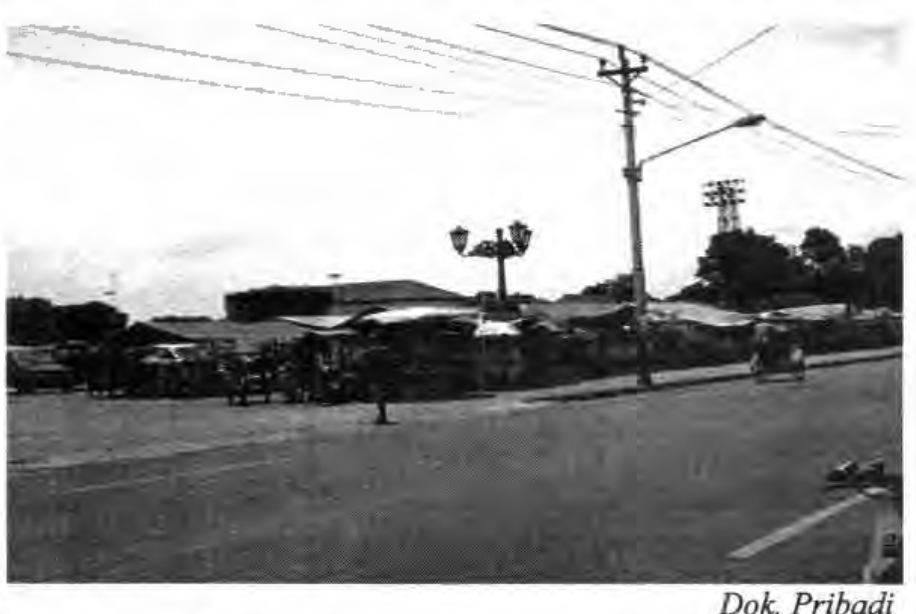

Pedagang semi menetap di pinggir alun-alun bagian dalam lokasi yang diprioritskan untuk kegiatan-kegiatan yang bersifat umum, misalnya untuk olah raga. 
c. Kelompok tidak menetap. Berbeda dengan kelompok pertama dan kedua, kelompok ini tidak menetap pada tempat tertentu. Oleh karena itu, kelompok ini lebih leluasa dalam bergerak. Berdasarkan sifatnya tersebut keberadaan mereka juga hanya pada waktu-waktu tertentu saja, yaitu jika ada wisatawan datang. Ada tidaknya wisatawan dapat mereka ketahui jika di alun-alun ada bis parkir. Biasanya mereka datang tanpa membawa barang dagangan. Jika kemudian diketahui di alun-alun ada bis sedang parkir, maka mereka segera pergi untuk mengambil barang dagangannya. Lokasi mereka menggelar dagangan ada di depan regol MBK. Sementara lokasi ini menjadi tempat parkir bis wisatawan. Dengan demikian, di lokasi ini terdapat beberapa kegiatan yang saling tumpang tindih, yaitu kios pedagang menetap,

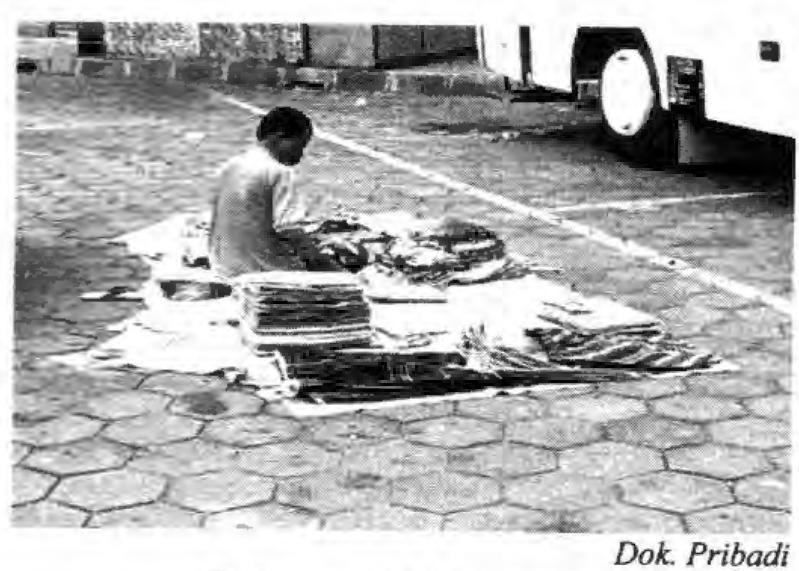

Pedagang tidak menetap menghadapi bis yang sedang parkir pedagang tidak menetap, dan tempat parkir.

Melihat kenyataan dengan adanya ketiga jenis pedagang tersebut dapat dibayangkan betapa ketidak teraturan kegiatan di depan regol MBK. Keadaan seperti itu, ditambah dengan para penarik becak yang menunggu penumpang di depan regol masjid. Di samping itu, adanya sampah yang dihasilkan akibat kegiatan tersebut, menambah semakin tidak sedap dipandang. Walaupun di lokasi ini telah disediakan beberapa tong sampah.

\section{Keberadaan Para Penarik Becak}

Pada dasarnya keberadaan becak tidak jauh berbeda dengan para pedagang yang tidak menetap. Tanpa ragu-ragu mereka menawarkan jasanya kepada para wisatawan untuk dapat mengantarkan ke suatu tempat tertentu. Keberadaan para tukang becak di depan regol MBK telah dikoordinir dalam sebuah wadah yang dinamakan Paguyuban PAN MABES, artinya Paguyuban Depan Masjid Besar. Walaupun demikian, tetap saja masih sering menimbulkan keprihatinan di kalangan wisatawan dan warga sekitar, yaitu:

a. Para tukang becak dalam memarkir becaknya sering tidak mengindahkan pemakai jalan yang lain, yaitu bergerombol di depan regol masjid dan terlalu ke tengah, sehingga mengganggu wisatawan yang akan memasuki kompleks MBK dan lalu lintas yang melewati jalan tersebut. 
b. Para tukang becak dalam memasang tarif terlalu tinggi untuk ukuran jarak yang ditempuh. Agar tidak kelihatan mahal, maka para wisatawan dalam perjalanan menuju ke tempat tujuan melewati jalan yang memutar agar kelihatan jauh. Walaupun sebenarnya ada jalan lain yang lebih dekat. Memang tidak semua tukang becak menerapkan taktik yang demikian.

Dengan melihat kedua hal tersebut banyak para wisatawan yang kecewa, terutama wisatawan yang telah beberapa kali mengunjungi MBK, misalnya para guru pembimbing yang setiap tahun selalu mengantarkan anak didiknya mengunjungi objek-objek wisata yang ada di Yogyakarta.

\section{Areal Parkir}

Berkaitan dengan areal parkir sebetulnya Pemerintah Daerah telah menentukan lokasinya yaitu di Jalan Wakhir Hasyim, tepatnya di belakang (barat) bekas Stasiun Ngabean. Pada kenyataannya lokasi tersebut belum digunakan secara maksimal, sebab baru beberapa bus yang "rela" menggunakan fasilitas yang telah disediakan. Sebagian besar lebih senang memarkir kendaraan mereka di depan regol MBK dan Alun-alun

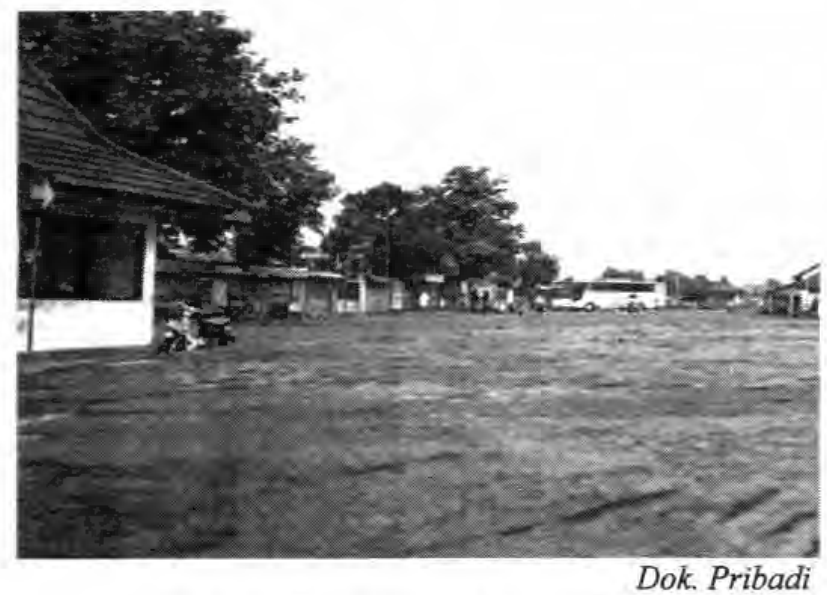

Areal parkir yang telah disediakan oleh Pemda selalu sepi Utara, mengingat jaraknya tidak jauh dari objek wisata, yaitu kraton, masjid, dan Malioboro. Sementara lokasi parkir yang disediakan Pemda jaraknya kurang lebih $1 \mathrm{~km}$ dari objek wisata tersebut.

Keadaan yang demikian ini tentunya berimbas kepada:

a. Areal parkir yang telah disediakan belum dapat difungsikan sebagaimana mestinya secara maksimal. Akibat selanjutnya Pemda yang telah membangun areal parkir tidak mendapat pemasukan dari jasa perparkiran tersebut,

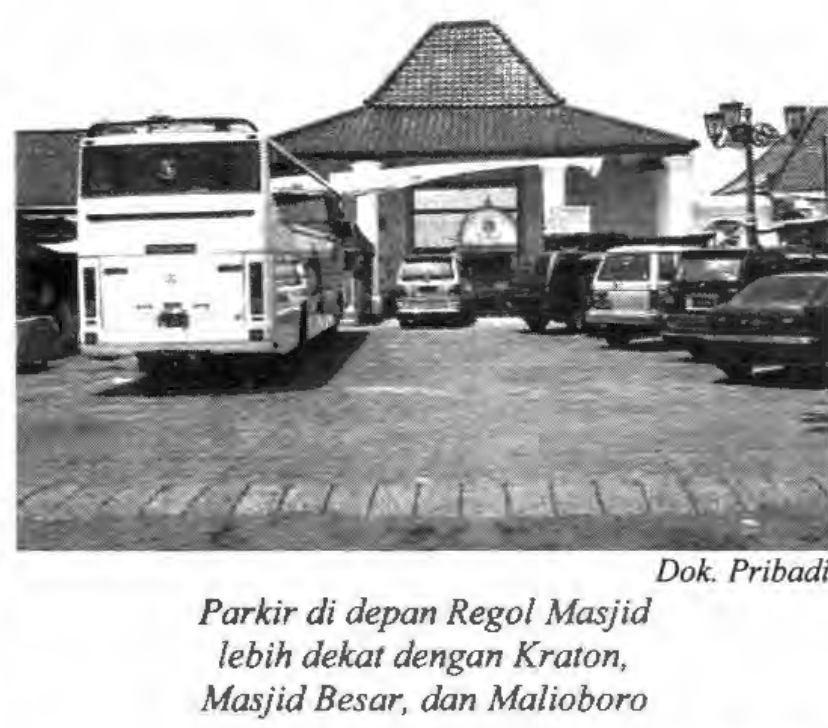


sehingga pendapatan asli daerah (PAD) bagi Pemda berkurang.

b. Wisatawan yang akan memasuki kompleks MBK dengan melewati regol terganggu adanya bus-bus yang sedang parkir, PKL yang tidak menetap, dan becak-becak yang sedang parkir.

\section{Analisis Konflik}

Konflik-konflik yang ada di Masjid Besar berdasarkan sifatnya dapat dikelompokkan menjadi dua, yaitu

a. Konflik langsung, yaitu bentuk-bentuk konflik yang secara langsung berkaitan erat dengan pengelolaan dan pemanfaatan MBK.

b. Konflik tidak langsung, yaitu bentuk-bentuk konflik yang secara tidak langsung berkaitan tetapi dikhawatirkan akan dapat mempengaruhi pengelolaan dan pemanfaatan BCB MBK.

Berdasarkan sifat konflik seperti tersebut di atas jika dikaitkan dengan bentuk dan struktur konflik dapat dilihat pada tabel di bawah ini, yaitu:

\begin{tabular}{|c|c|c|c|c|}
\hline \multirow{2}{*}{ No. } & \multirow{2}{*}{ Bentuk Konflik } & \multicolumn{2}{|c|}{ Sifat Konflik } & \multirow{2}{*}{ Strktur Konflik } \\
\hline & & Langsung & Tdk Langsung & \\
\hline 1. & Penginapan & V & -- & $\begin{array}{l}\text { Antara Takmir MBK } \\
\text { dengan oknum dan } \\
\text { wisatawan }\end{array}$ \\
\hline 2. & Kamar Mandi & V & --- & $\begin{array}{l}\text { Antara Takmir MBK } \\
\text { dengan oknum dan } \\
\text { wisatawan }\end{array}$ \\
\hline 3. & Pengemis & V & $\cdots$ & $\begin{array}{l}\text { Antara Takmir MBK dan } \\
\text { wisatawan dengan } \\
\text { pengemis }\end{array}$ \\
\hline 4. & $\begin{array}{l}\text { Pedagang Kaki } \\
\text { Lima }\end{array}$ & -- & V & $\begin{array}{l}\text { Antara Pemda dan } \\
\text { DLLAJ (?) dengan PKL }\end{array}$ \\
\hline 5. & Penarik Becak & -- & V & $\begin{array}{l}\text { Antara DLLAJ dengan } \\
\text { penarik becak }\end{array}$ \\
\hline 6. & Areal Parkir & --- & V & $\begin{array}{l}\text { Antara Pemda dengan } \\
\text { petugas parkir }\end{array}$ \\
\hline
\end{tabular}

Berdasarkan tabel di atas secara rinci dapat diketahui bahwa terdapat beberapa kelompok yang berkonflik, yaitu:

1. Antara Takmir Masjid dengan oknum yang mengatasnamakan Pengurus Takmir, dan wisatawan, serta pengemis.

2. Antara Pemerintah Daerah Kota Yogyakarta dengan PKL dan petugas parkir.

3. Antara Dinas Lalu Lintas Angkutan Jalan dengan penarik becak dan PKL (?). 
Selanjutnya dengan melihat akar permasalahan terjadinya konflik dapat dibedakan menjadi sembilan hal berdasarkan asal usul atau kelompok yang berkonflik, yaitu:

1. Pengurus Takmir Masjid Besar Kauman

2. Pemerintah Daerah Kota Yogyakarta

3. Dinas Lalu Lintas Angkutan Jalan

4. Oknum yang mengatasnamakan Pengurus Takmir MBK

5. Wisatawan

6. Para Penarik Becak

7. Pedagang Kaki Lima

8. Petugas Parkir

9. Pengemis

Setelah dicermati, dari kesembilan asal usul atau kelompok yang berkonflik tersebut dapat dibagi menjadi 3 berdasarkan materi konflik, yaitu:

\begin{tabular}{|c|l|c|c|c|}
\hline \multirow{2}{*}{ No. } & \multirow{2}{*}{ Bentuk Konflik } & \multicolumn{3}{c|}{ Materi Konflik } \\
\cline { 3 - 5 } & & Pemanfaatan & Tiblantas & Uang \\
\hline 1. & Takmir MBK & $\mathrm{V}$ & --- & --- \\
\hline 2. & Pemerintah Daerah Yk & --- & --- & V \\
\hline 3. & DLLAJ & --- & $\mathrm{V}$ & --- \\
\hline 4. & Oknum & --- & --- & V \\
\hline 5. & Penarik Becak & --- & --- & V \\
\hline 6. & Pedagang Kaki Lima & --- & --- & V \\
\hline 7. & Petugas Parkir & --- & --- & V \\
\hline 8. & Pengemis & --- & --- & V \\
\hline
\end{tabular}

\section{Keterangan:}

Khusus untuk "wisatawan" tidak dimasukkan dalam tabel di atas karena selaku "subyek" yang mengunjungi $\mathrm{BCB}$, walaupun kenyataannya wisatawan tersebut juga menimbulkan konflik.

Melihat kenyataan berdasarkan tabel di atas secara prosentase diketahui bahwa materi konflik yang berkaitan dengan uang $(75 \%)$, pemanfaatan $(12,5 \%)$, dan tiblantas $(12,5 \%)$. Dengan demikian, materi konflik yang paling pokok berkaitan dengan uang. Hal ini dapat dimaklumi karena masing-masing yang terlibat dalam konflik berusaha sekuat tenaga untuk dapat memanfaatkan objek (masjid) maupun lahan yang ada di sekitar MBK untuk memperoleh keuntungan pribadi secara materi (uang). Sedangkan di lain pihak kepentingan mereka untuk mendapatkan uang tersebut terbentur dengan kepentingan lain yang "lebih besar" yaitu pengelola masjid yang juga berusaha dengan sekuat tenaga untuk melestarikan 
dan memanfaatkannya sesuai dengan peraturan seperti yang telah digariskan dalam UU RI No. 5 Tahun 1992 seperti tersebut dalam Latar Belakang Permasalahan.

Dengan adanya perbedaan kepentingan dalam pengelolaan MBK tersebut, terdapat dua akibat yang ditimbulkan, yaitu:

a. Kelestarian MBK (objek) terabaikan, termasuk di dalamnya kerusakan BCB kurang diperhitungkan.

b. Masyarakat tidak atau kurang mengetahui nilai penting objek sebagai warisan budaya yang harus dilindungi.

Analisis konflik di atas menerapkan alat bantu yang berupa Pohon Konflik (Setyowati, 2004: 5) yang terdiri atas:

a. Faktor-faktor penyebab konflik yang terdiri atas enam dan berupa bentuk konflik, yaitu: penginapan, kamar mandi, pengemis, pedagang kaki lima, penarik becak, dan areal parkir.

b. Isu konflik yang terdiri atas tiga dan berupa materi konflik, yaitu: pemanfaatan, tiblantas, dan uang.

c. Akibat konflik yang terdiri atas dua hal yaitu berkaitan dengan kelestarian $\mathrm{BCB}$ dan nilai penting $\mathrm{BCB}$ bagi masyarakat.

\section{Bentuk Upaya Penyelesaian Konflik}

Berkaitan dengan hal tersebut (bentuk-bentuk konflik yang ada), maka konflikkonflik yang timbul akan diusahakan untuk dapat dikelola sedemikian rupa. Hal ini mengingat yang namanya konflik tidak selamanya berbau negarif. Konflikkonflik tersebut kadangkala diperlukan dalam upaya pelestarian dan pemanfaatan BCB. Untuk itu konflik-konflik yang ada dicoba untuk dikelola melalui pendekatan cultural resource management (CRM). Dalam hal ini CRM harus dipandang sebagai upaya pengelolaan warisan budaya secara bijak dengan mempertimbangkan kepentingan banyak pihak yang saling bertentangan. CRM lebih berkiblat pada upaya mencari jalan keluar terbaik agar kepentingan berbagai pihak sebanyak mungkin dapat terakomodasi, dan bukan semata-mata pada upaya pelestariannya (Tanudirjo, 1998: 15).

Selanjutnya Tanudirjo memberikan contoh berbagai aspek dari manajemen konflik yang ada di dalam CRM yang secara langsung dapat dilihat dalam Undang-undang Republik Indonesia yang sudah ditetapkan. Dalam UU RI No. 4 Tahun 1982 tentang Ketentuan-ketentuan Pokok Pengelolaan Lingkungan Hidup (UULH) dan PP No. 29 Tahun 1986 tentang Analisa Mengenai Dampak Lingkungan, warisan budaya atau benda cagar budaya ditetapkan sebagai komponen lingkungan hidup yang apabila terancam kena dampak suatu proyek haruslah dibuatkan AMDAL. Sementara itu UU RI No. 5 Tahun 1992 tentang 
Benda Cagar Budaya (UU BCB) beserta PP No. 10 Tahun 1993 tentang Pelaksanaan UU BCB menyatakan bahwa rencana kegiatan yang dapat mencemarkan, merusak, mengubah, dan memusnahkan benda cagar budaya dan lingkungannya harus dilaporkan kepada Menteri Pendidikan dan Kebudayaan (Tanudirjo, 1998: 15).

Pengelola MBK sementara ini merasa "kebingungan". Di satu pihak ingin melestarikan dan memanfaatkan objek sesuai dengan peraturan yang ada, di lain pihak terbentur adanya kenyataan bahwa MBK ini secara yuridis formal belum ditetapkan sesuai dengan undang-undang kepurbakalaan yang ada. Kebingungan tersebut khususnya berkaitan dengan penataan kawasan yang secara operasional mestinya terwujud dalam bentuk zoning (pemintakatan). Di dalam pemintakatan telah diatur batas-batas sesuai dengan peruntukannya. Terdapat 3 (tiga) pembagian wilayah (zoning) (Widianto dkk, 1996: 19), yaitu:

a. Wilayah pertama merupakan inti yaitu lahan situs yang mendapat perlakuan perlindungan mutlak.

b. Wilayah kedua merupakan penyangga yaitu lahan yang berfungsi sebagai penyangga mintakat inti.

c. Wilayah ketiga merupakan pengembangan yaitu lahan yang dapat dikembangkan atau difungsikan sebagai daerah pendidikan/wisata

Untuk memecahkan konflik yang terjadi di MBK, di dalam buku Teori Budaya terdapat "Teori Fungsionalisme" yang merupakan metodologi untuk mengeksplorasi saling ketergantungan. Teori ini bertumpu pada perumpamaan organisme, di mana di dalamnya terdapat sistem sosial budaya yang tidak saja saling berhubungan melainkan juga memberikan andil bagi pemeliharaan, stabilitas, dan kelestarian hidup organisme itu sendiri. Untuk itu sistem budaya mempunyai syarat-syarat tertentu agar keberadaannya diakui, tetapi jika hal itu tidak dipenuhi maka sistem tersebut akan mengalami disintegrasi atau bahkan akan berubah menjadi sistem lain yang berbeda jenis (Kaplan dan Manners, 2002: 77 - 78). Dengan mengacu pada teori fungsionalisme tersebut, individu atau kelompok yang berkonflik diibaratkan sebagai sebuah organisme. Masing-masing mempunyai tugas dan fungsi sesuai dengan perannya. Mereka yang berkonflik seharusnya menyadari bahwa masing-masing darinya merupakan bagian yang utuh yang tidak dapat dipisahkan satu dengan lainnya. Mereka tidak dapat berdiri sendiri, akan tetapi saling tergantung. Masjid tidak akan kelihatan semarak tanpa kehadiran wisatawan, pedagang kaki lima, tukang becak, pengemis dll, demikian juga sebaliknya.

Selanjutnya dikatakan bahwa agar sistem tersebut diakui keberadaannya, diperlukan adanya beberapa syarat, yaitu: a) jaminan adanya hubungan yang memadai dengan lingkungan; b) diferensiasi peran dan pemberian peran; c) komunikasi; d) perangkat tujuan yang jelas dan disangga bersama; e) pengaturan 
normatif atas sarana-sarana; f) pengaturan ungkapan afektif; g) sosialisasi; dan h) kontrol efektif atas bentuk-bentuk perilaku mengacau (disruptif) (Kaplan dan Manners, 2002: 87).

Oleh karena itu untuk mengantisipasi agar konflik yang ada tidak semakin membesar dan membuat jarak di antara para individu atau kelompok yang berkonflik, maka perlu diadakan komunikasi dua arah antar mereka. Komunikasi merupakan salah satu syarat dari delapan (8) syarat yang diajukan. Solusi ini kemungkinan merupakan jalan terbaik untuk menyelesaikannya.

Berdasarkan tabel di atas (lihat pada C. Analisis Konflik) yang berkaitan dengan bentuk konflik diketahui bahwa dari delapan (8) bentuk konflik yang ada, lima (5) di antaranya berkaitan langsung dengan masyarakat. Masyarakat yang dimaksud adalah yang berdiam di sekitar objek (MBK). Oleh karena itu dalam pengelolaan sumberdaya budaya (khususnya MBK) masyarakat sekitar objek perlu dilibatkan agar keberadaannya tidak menjadi kendala akan tetapi justru dapat lebih menghidupkan suasana MBK. Penyertaan masyarakat dalam pengelolaan sumberdaya budaya dikenal dengan pemberdayaan (empowerment). Seperti telah diuraikan di atas bahwa materi konflik yang berkaitan dengan uang (75\%). Untuk itu pemberdayaan masyarakat melalui pendekatan ekonomi merupakan hal yang paling masuk akal. Pemberdayaan masyarakat melalui bidang ini (ekonomi) merupakan upaya pemberdayaan yang paling banyak dilaksanakan karena kegiatan ini secara langsung berkaitan dengan pemenuhan kebutuhan primer manusia. Pemberdayaan melalui bidang ini dimaksudkan agar masyarakat dapat memiliki akses terhadap pengelolaan dan pemanfaatan sumberdaya ekonomi untuk mencari nafkah (Prasodjo, 2004: 5).

\section{E. Penutup}

Dalam upaya pelestarian, perlindungan, dan pemanfaatan BCB MBK Yogyakarta berkaitan dengan konflik-konflik kepentingan yang ada di dalamnya, maka upaya penyelesaiannya dapat melalui beberapa hal, yaitu:

1. Bentuk-bentuk konflik yang ada diusahakan untuk dapat dikelola sedemikian rupa, mengingat yang namanya konflik tidak selamnya berbau negarif. Konflik-konflik tersebut kadang kala diperlukan dalam upaya pelestarian dan pemanfaatan BCB.

2. Bentuk-bentuk konflik yang ada dapat dikelola melalui pendekatan CRM yaitu sebagai upaya bentuk pengelolaan warisan budaya.

3. Materi konflik yang paling utama berkaitan dengan uang.

4. Upaya pendekatan yang dilakukan melalui bentuk komunikasi dua arah antar mereka yang berkonflik.

5. Pemberdayaan masyarakat sekitar MBK perlu diperhitungkan. 


\section{DAFTAR PUSTAKA}

Chawari, Muhammad. 1989. Pasang Surut Perkembangan Pembangunan Masjid Besar Kauman Yogyakarta: Studi Berdasarkan Sumber Prasasti. Skripsi. Jurusan Arkeologi, Fakultas Sastra, Universitas Gadjah Mada, Yogyakarta.

Kaplan, David dan Albert A. Manners. 2002. Teori Budaya. Pustaka Pelajar, Yogyakarta.

Peraturan Pemerintah No. 29 Tahun 1986 tentang Analisa Mengenai Dampak Lingkungan (AMDAL).

Peraturan Pemerintah No. 10 Tahun 1993 tentang Pelaksanaan Undang-undang Benda Cagar Budaya.

Prasodjo, Tjahjono. 2004. Pemberdayaan Masyarakat dalam Pengelolaan Sumberdaya Arkeologi. Pelatihan Pengelolaan Sumberdaya Arkeologi Tingkat Dasar, Mojokerto.

Setyowati, Endah. 2004. Materi Workshop Analisis Konflik. Program S2 Arkeologi Universitas Gadjah Mada, Yogyakarta.

Tanudirjo, Daud Aris. Cultural Resource Management sebagai Manajemen Konflik.

Artefak No. 19. Himpunan Mahasiswa Arkeologi (HIMA), Fakultas Sastra, Universitas Gadjah Mada, Yogyakarta.

Undang-undang Republik Indonesia RI No. 4 Tahun 1982 tentang Ketentuanketentuan Pokok Pengelolaan Lingkungan Hidup (UULH).

Undang-undang Republik Indonesia Nomor 5 Tahun 1992 tentang Benda Cagar Budaya (BCB).

Widianto, Harry, dkk. 1996. Laporan Studi Pemintakatan Situs Sangiran. Bagian Proyek Pembinaan Peninggalan Sejarah dan Kepurbakalaan Jawa Tengah. 